\title{
Çocukluk Çağı Cinsel İstismarına Maruz Kalan Bireylerle Varoluşçu Sosyal Grup Çalışması
}

\author{
Betül ÇOLAK*
}

\section{$\ddot{O} \mathbf{z}$}

Çocukluk çağı cinsel istismarı çocuğa yönelik kötü muamele türlerinden biridir ve günümüzde hem ulusal hem uluslararası boyutta görünürlüğü giderek artan önemli bir sorundur. Çocukluk döneminde cinsel istismarın çocuk üzerinde tamamen tamir edilemez ancak azaltılabilir kısa ve uzun dönemli olmak üzere etkileri vardır. Bu etkiler bireyin yetişkinlik dönemini de etkileyerek hayatını yönlendirecek derecede önemli olan olumsuz etkilerdir. Sosyal hizmet teori ve uygulamalarında çocuğun cinsel istismarına ilişkin önemli bir bilimsel arka plan vardır. Çocuğun cinsel istismarının anlaşılması ve çözümü için birden fazla bilim alanı ve hizmet biriminin birlikte çalışması gerekmektedir. Sosyoloji, psikoloji, felsefe, sosyal politika bu bilimlerden bazılarına örnektir. Psikoloji bilimi, cinsel istismarın çocuk üzerindeki psikolojik etkilerini sağaltmak ve yetişkinlik döneminde sağlıklı bir yaşam sürdürmesini sağlamak için çalışan bilim dallarından biridir ve sosyal hizmet bilimsel birikimini ve uygulamalarını da beslemektedir. Sosyal hizmet kurum ve kuruluşlarında müracaatçllarla yapılan bireysel ve grup görüşmelerinde, sosyal hizmet bilgisinin yanı sıra eklektik ve interdisipliner yaklaşım kullanılmaktadır. Çocukluk çağı cinsel istismarının yaşam boyu süren etkilerinin sağaltılmasında psikolog ve psikiyatristlerin çalışmalarının yanı sıra sosyal hizmet kurum bakımı sürecinde çocuklara ve kurum bakımı süreci sonrasında yetişkinlik döneminde bireylere sosyal çalışmacılar tarafından da destek sunulmaktadır. Bu makalede, bu destek hizmetlerinden ve sosyal hizmetin mezzo düzey yöntemlerinden biri olan sosyal grup çalışmasında felsefe temelli olan ancak psikolojide de kullanılan Varoluşçu Terapinin sosyal hizmet alanında kullanımına odaklanılmıştır. Bu bağlamda derlemenin amacı, çocukluk çağı cinsel istismar mağduru bireylerle varoluşçu sosyal grup

Derleme Makale (Review Article)

Geliş / Received: 04.08.2020 \& Kabul / Accepted: 29.11.2020

DOI: https://doi.org/10.38079/igusabder.776801

* Öğr. Gör., İstanbul Gelişim Üniversitesi, Sağllk Bilimleri Yüksekokulu, Sosyal Hizmet Bölümü, İstanbul, Türkiye, E-posta: becolak@gelisim.edu.tr ORCID https://orcid.org/0000-0002-0051$914 \mathrm{X}$ 
çalışmasının nasıl gerçekleştirileceğini, işlevselliğini ve etkilerini literatür bilgileri ışığında sunmaktır.

Anahtar Kelimeler: Sosyal hizmet, varoluşçu sosyal grup çalışması, çocukluk çağı cinsel istismarı.

\title{
Existential Social Group Work with Individuals Exposed to Childhood Sexual
}

\section{Abuse}

\begin{abstract}
Childhood sexual abuse is one of the types of child maltreatment and it is an important problem which has increasing visibility on both national and international dimensions. Childhood sexual abuse has short and long term effects on a child that can not be fully repaired but can be diminished. These effects are negative effects that are important enough to direct the life of the individual by affecting adulthood. In social work theories and practices, there is an accumulation of knowledge and scientific background regarding child sexual abuse. More than one field of science and service units need to work together to understand and resolve child sexual abuse. Sociology, psychology, philosophy, and social policy are examples of some of these sciences. Psychology is one of the branches of science that works to improve the psychological effects of sexual abuse on the child and ensure a healthy life in adulthood, and also nurtures the scientific knowledge and practices of social work. Eclectic and interdisciplinary approach, as well as social service information, is used in individual and group interviews with clients at social service institutions and organizations. In addition to the work of psychologists and psychiatrists in the treatment of lifelong effects of childhood sexual abuse, social services are provided to children in the institutional care process and to individuals in the adulthood period after institution care. This article focuses on the use of Existential Therapy which is philosophy-based but also used in psychology, in social group work which is one of these support services and mezzo-level methods of social work. In this context, the aim of the review is to present how to carry out existential social group work, its functionality and effects for individuals who are victims of sexual abuse, in the light of the literature.
\end{abstract}

Keywords: Social work, existential social group work, childhood sexual abuse.

\section{Giriş}

Çocuğun cinsel istismarı günümüzde giderek görünür olmaya başlayan, görünürlüğünün artmasından dolayı sayısında da artış olduğu algısını yaratan güncel, önemli ve birçok bileşeni olan hassas bir sorundur. Şiddetin tarihini inceleyen çalışmalara bakıldığında, 
çocuğun cinsel istismarı, dünyada her dönemde görülen ve dolayısıyla aslında her zaman güncel olan ciddi bir sosyal problem olarak karşımıza çıkmaktadır. Ancak günümüzde çok daha fazla ihbar edilmekte ve sorgulanmaktadır ${ }^{1}$. Çocuğun cinsel istismarı, nedenlerinin ve sonuçlarının çok yönlü olması ve farklı bileşenlerden oluşması nedeniyle müdahalesinde farklı disiplinlerin bir arada bütüncül yaklaşımını gerektirmektedir. $\mathrm{Bu}$ sorunla en etkili ve aktif şekilde çalışan disiplinlerin başında sosyal hizmet gelmektedir.

Sosyal hizmet; sosyal değişimi ve gelişimi, sosyal bütünleşmeyi, insanların güçlendirilmesini ve özgürleşmelerini destekleyen uygulama temelli bir meslek ve akademik disiplindir. Sosyal hizmet, sosyal adalet, insan hakları, ortak sorumluluk ve farklılıklara saygı ilkelerini merkeze alır. Sosyal hizmet teorileri, beşeri bilimler, sosyal bilimler ve yerel bilgi ile desteklenen sosyal hizmet, yaşam zorluklarıyla mücadele etmek ve iyilik halini geliştirmek için insanlarla ve yapılarla çalışır². Çocukluk çă̆ı cinsel istismarı sosyal hizmetin çalışma alanlarından biri olan çocuk refah alanına giren sorun alanlarından biri ve çocukluk çağı cinsel istismarına maruz kalan bireyler de sosyal hizmet tanımında yer alan, yaşam zorluklarıyla mücadele etmek ve iyilik halini geliştirmek amacı kapsamına giren dezavantajlı müracaatçı gruplardan biridir. Çocukluk çă̆ı cinsel istismarına müdahalede birey, grup ve toplum düzeyinde sosyal hizmet bilgisi, müdahale yöntem ve teknikleri kullanır. Bu çalışma, çocukluk dönemi cinsel istismar mağduru bireylerle sosyal hizmetin müdahale yöntemlerinden bir olan grupla sosyal çalışma yöntemine odaklanana ve varoluşçu terapinin grupla sosyal çalışmada kullanılmasının önemine vurgu yapan bir derleme çalışmasıdır. Çalışmada öncelikle çocuğun cinsel istismarı, çocuğa etkileri ve varoluşçu terapi ele alınmış, bunlara ilişkin literatür bilgileri sunulmuş ve daha sonra grupla sosyal çalışmada varoluşçu terapinin çocuk cinsel istismarı konusu özelinde uygulanılışı ve önemi ele alınmıştır.

\section{Çocukluk Dönemi Cinsel İstismarı ve Çocuğa Etkileri}

Dünya Sağlık Örgütü’ne göre çocuğa yönelik kötü muamele; bir sorumluluk, güven veya güç ilişkisi bağlamında, çocuğun sağlığı, yaşamı, gelişmesi ve saygınlığı açısından, fiilen zararlı veya potansiyel olarak zararlı sonuçlar verebilecek her tür fiziksel ve/veya duygusal kötü muamele, cinsel istismar, ihmal veya ihmalkâr davranış veya ticari amaçlı, ya da başka tür sömürü olarak tanımlanmaktadır³. Cinsel istismar tanımda belirtildiği üzere çocuğa yönelik kötü muamelenin kapsamına girmektedir. Çocuğa yönelik cinsel istismarın tanımına ilişkin ise literatürde çeşitli tanımlar vardır. Çocuğun cinsel istismarı 
ilk olarak 'bağımlı ve gelişimsel olarak olgunlaşmamış çocuk ve ergenlerin bilinçli olarak onay vermeye muktedir olmadıkları ve bütünüyle algılayamadıkları veya ailevi rollerle ilgili sosyal tabulara ters düşen cinsel eylemlerde taraf olmaları’ şeklinde tanımlanmıştır. Kempe ve arkadaşları tarafından kurulan Uluslararası Çocuk İstismarı ve İhmalini Önleme Derneği, çocuk cinsel istismarını 'rıza yaşının altında bulunan bir çocuğun cinsel açıdan olgun bir yetişkinin cinsel doyumuna yol açacak şekilde bir edim içinde yer alması ya da bu duruma göz yumulması' şeklinde tanımlamıştır ${ }^{4}$. Finkelhor ve Brown, cinsel istismarı 18 yaşından küçük bir çocuğa kendinden beş yaş veya daha büyük biri tarafından, üstü kapalı veya açık bir şekilde zor kullanarak yapılan herhangi bir cinsel faaliyet olarak tanımlamıştır ${ }^{5}$. Dağlı ise tanımın kapsamını biraz daha genişleterek çocuğun cinsel istismarını, bir çocuk ile bir yetişkin ya da yaş ve gelişim bakımından sorumluluk, güven ve güç ilişkisi içinde olan başka bir çocuk arasında, bu kişinin cinsel gereksinimlerini tatmin etmeyi amaçlayan bir eylem şeklinde tanımlamaktadır6.

Çocuğun cinsel istismarı her yaştan, farklı sosyoekonomik düzeyden ve kültürel altyapıdan çocuğu etkileyen yaygın bir sorun² olarak karşımıza çıkmaktadır. Ensest ise cinsel istismarın bir türü olup literatürde hukuki ve psiko-sosyal bağ dinamiklerine göre farklı biçimlerde tanımlanmaktadır. Hukuki tanıma göre ensest, evlenmeleri yasak olan reşit kişiler arasındaki rızaya dayalı cinsel ilişkidir. Bu tanıma göre ensest aralarında kan bağı bulunan ve evlilikleri kanunla engellenen (anne-oğul, baba-kız, dede-torun, kayınpeder-gelin, kardeşler...) akrabalar arasındaki cinsel ilişki olarak tanımlanmaktadır?.

Bir başka tanıma göre ensest, kanunen evlenmesine izin verilmeyen iki kişi arasındaki cinsel ilişki, aile ilişkileri çerçevesinde uygunsuz cinsel davranış olarak tanımlanmıştır. Cinsel istismarın aile içinde yaşanması, toplum tarafından kabul edilemezliği ve ailenin parçalanma korkusu gibi etmenler ensestin diğer cinsel istismar tiplerine göre açı̆̆a çıkmasını zorlaştırmaktadır ve mağdurlarda diğer tiplere göre daha ağır ve uzun süreli hasar meydana gelmektedir8 ${ }^{8}$ Çocukluk dönemi cinsel istismarlarının büyük bir kısmını çocuğun aile içindeki cinsel istismarı, ensest oluşturmaktır9.

Çocuğun cinsel istismarı ile ilgili dünya genelinde yapılan araştırmalarla ulaşılan verilere bakıldığında, kadınların yaklaşık \%20'sinin ve erkeklerin yaklaşık \%5-10’unun çocukluk dönemlerinde cinsel istismara maruz kaldığı tespit edilmiştir ${ }^{10}$. Her beş kız çocuğundan biri cinsel istismara uğramaktadır ve bazı ülkelerde bu oranın her üç kız çocuğundan 
birine yaklaştığı tahmin edilmektedir. Çocukluk çağı cinsel istismarının yaşam döngüsü içindeki yaygınlık oranına bakıldığında cinsiyete göre farklılık olduğu görülmektedir. Bu oran kızlarda \%18, erkeklerde \%7,6’dır. Dünya Sağlık Örgütü’nün (DSÖ) Şiddetin Önlenmesine Yönelik Dünya Raporunda 133 ülkenin şiddetin farklı türlerine ilişkin verdikleri ulusal yaygınlık araştırmalarının ortalamasına göre, çocuğa yönelik kötü muamele \%41, cinsel şiddet \%57'dir. DSÖ, cinsel şiddetin \%52'lik oranla, bütün gelir seviyeleri içinde görülen şiddetin en baskın biçimi olduğunu belirtmişlerdir ${ }^{9}$.

Türkiye'deki duruma bakıldığında, End Child Prostitution, Child Pornography and Trafficking of Children for Sexual Purposes (ECPAT)'ın 2019 yılında çocukların cinsel istismarını ve sömürüsünü engellemek üzere yapılan çalışmalar ve risk faktörlerinin değerlendirildiği Gündüz Gözüyle Endeksine göre Türkiye'nin 60 ülke arasından 18. sırada olduğu görülmektedir ${ }^{11}$. TÜİK’in cinsel suç mağduru çocuklara ilişkin yayınladığı son veriler 2017 yılına aittir. Bu verilere göre erkek ve kız olmak üzere cinsel suç mağduriyeti toplam 18.623'tür ${ }^{12}$. Bu sayı sadece adli sürece dahi olanların sayısıdır. Hem ulusal hem uluslararası veriler konunun yaygınlığını görmek açısından önem arz etmektedir.

2009 yılında Nüfus Bilim Derneği ve Birleşmiş Milletler Nüfus Fonu tarafından “Türkiye'de Ensest Sorununu Anlamak" adlı araştırma13 enseste maruz kalanlarla süreç içinde bir araya gelen farkı mesleklerden uzmanlarla -öğretmen, hekim, ebe, polis, hâkim, savcı, avukat, psikolog, sosyal çalışmacı, sosyolog ve sivil toplum kurumu çalışanlarından oluşan- toplam 98 kişi ile yapılmış derinlemesine görüşmelere dayanmaktadır. Araştırmada her yaşta ve farklı sosyoekonomik özelliklere sahip failin, her yaştan kız ve erkek çocuğuna yönelik cinsel istismar örneklerine rastlanmıştır. Uzmanlar enseste tüm sosyoekonomik gruplardan ailelerde rastlanabileceği görüşündedir. Uzmanların aktardıkları ensest olaylarının gerçekleştiği aileler daha çok düşük gelir düzeyinde olsa da, uzmanlar bu durumu düşük gelir gruplarından ailelerin toplumun genelinden daha fazla sayıda olması ve ekonomik gücün ensestin gizlenmesini kolaylaştıran bir faktör olmasıyla açıklamışlardır ${ }^{14}$. Cinsel istismar ve ensestin oluşma ve ortaya çıkma dinamikleri çok değişkenli ve komplekstir.

Çocuğun cinsel istismarı ihbar, başvuruya da öğretmenlerin fark etmesi ile ortaya çıkmaktadır. Sonrasında kolluk kuvvetleri çocuğun ifadesi alınmakta, ifadeden sonra sağlık muayenesi yapılmakta ve çocuk İlk Adım merkezine gönderilmektedir. Burada 
çocuğun kurum bakımına alınıp alınmayacağına, alınacaksa hangi kuruma sevk edileceği belirlenmekte alınmayacaksa aile koşullarının uygunluğuna bakılmaktadır. Tüm bu süreç boyunca, üç gün ila iki hafta arasında, çocuk İlk Adım Merkezi’nde kalmakta ve sonra çoğunlukla Çocuk Destek Merkezleri’nde kurum bakımına alınmaktadır. Sosyal çalışmacılar tüm bu süreç boyunca farklı kurumlar bünyesinde çocuğa eşlik etmekte ve görevlerini yerine getirmektedirler. Çocuğun evden alınmasından kurum bakımına alındığı Çocuk Destek Merkezi’nden çıkana kadar çocuğun bakımı ve rehabilitasyonuna yönelik çalışmaları gerçekleştirmektedirler.

\section{Cinsel İstismarın Çocuğa Etkileri}

Her türlü şiddeti kapsayan çocuğa kötü muamele, yetişkinlik döneminde davranışsal, fiziksel ve psikolojik sorunlara neden olacak şekilde beyinde değişikliklere yol açmakta, çocuğun ergenlikte ya da yetişkinlik döneminde şiddetin diğer türlerinin mağduru ya da uygulayıcısı olma riskini artırmaktadır.

Cinsel istismarın etkilerini anlamak için dört maddeden oluşan bir paradigma geliştirilmiştir15: Travmatik cinsellik, ihanet, damgalanma ve güçsüzlük. Travmatik cinsellik, istismarcının çocuğa cinselliği özendirmesi ve onu cinsel eylem için özendirmesi ile gelişen bozukluklardır. $\mathrm{Bu}$, cinsel kimlik ve cinsel normlarda karmaşa, cinsellik ve sevginin karıştırılması, çarpık algılanması ve cinsel yakınlaşmadan tiksinmeyle sonuçlanır. İhanet; çocuğun onu sevmesi ve koruması gereken birinin ona zarar verdiğini fark etmesiyle gelişir. Depresyon, bağımlılık, güvensizlik, öfke ve düşmanlık duyguları ile sonuçlanır. Damgalanma; çocuğun suçlandığı ve çocuğa "kirli ve bozulmuş” olduğu mesajının verilmesidir. Suçluluk, utanç, düşük benlik saygısı ve soyutlanma ile sonuçlanır. Güçsüzlük; çocuğun bedeninin şiddete uğraması ve çocuğun şiddeti ve istismarı durdurmakta yetersiz hissetmesi ile gelişir. Anksiyete, korku ve öz yeterliliğin zayıflaması duygusuyla sonuçlanır ${ }^{16}$. Bu dört temel etki dışında ensest ve cinsel istismarın çocuk üzerindeki biyolojik, fiziksel, ruhsal diğer ve ayrıntılı etkileri; kognitif yıkım ve ilişkilerde dengesizlik, anksiyete, travma sonrası stres bozukluğu, gerçeği görmezden gelme, çarpıtma ${ }^{15}$, düşük benlik saygısı, damgalanma, utanç, suçluluk $^{16}$, kendine yönelik yıkıcı davranışlar, kendinden nefret etme ve vücut imajı ile ilgili kaygılar, depresyon, madde bağımlılı̆̆ı, intihar davranışı, borderline kișilik bozukluğ ${ }^{17}$ olarak literatürde yer almaktadır. Ayrıca, cinsel istismara maruz kişilerin bağlanma bozukluğu geliştirerek psikososyal açıdan bakıldığında ilişki kurmaktan uzak 
durdukları, yakınlık kurma ihtiyacıyla sayıca fazla ilişkiye yöneldikleri ve sonuç olarak da işlevsellikten uzak ve yalnızlıkla sonlanan ilişkiler kurdukları görülmektedir ${ }^{18}$. Cinsel istismarın psikolojik etkileri hem bireysel hem de grup çalışması yöntemleri ile rehabilite edilmektedir.

\section{Varoluşçuluk ve Varoluşçu Terapi}

Varoluşçuluk temelleri S. Kierkegaard, F. Nietzsche ile atılmış ve 20. yüzyılda J.P. Sartre, K. Jaspers ve M. Heidegger gibi düşünürlerce savunulmuş ve geliştirilmiş bir felsefe akımıdır. İradesi ve bilinci olan insanın, irade ve bilinçten yoksun nesneler dünyasına firlatılmış olduğunu öne süren felsefe okuludur. İnsanın önce var olduğunu daha sonra kendini tanımlayıp özünü yarattığını dile getirir¹9.

Varoluşçuluk felsefi bir akım olarak varoluşun anlamı, insanın kendini gerçekleştirmesi, hiçlik içinde insan, insanın güçsüzlüğü, ölümle hayatı sonlanacak olan insan, insanın kendini bulması, toplum içinde ve ahlaklılık karşısındaki tutumu gibi sorun ve konuları tartışır. Varoluş kavramını modern anlamda ilk kullanan düşünür Soren Kierkegaard'dır. Kierkegaard'a göre insanın varoluşunu sorgulaması açısından onu uyandıran şeyler, kaygı, korku ve iç daralmasıdır. Ancak korkuyu içinde bütün uyanıklı̆̆ı ile duyan ve bundan kaçamayan kişi, bu korku ile varoluşunun farkındalığını sürdürebilir. Karl Jaspers’a göre gerçek dünyanın saçmalığı ve kavranılamazlığı insanı içine çeker ve onu da kendisini de anlaşılmaz kılar. Ancak insanın dünya içinde tam bir karara varması ve anlamlı bir eyleme yönelmesi gerekir. İnsanın varoluşu, kendisi olma ya da insan olma ile mümkündür. Bu da özgür ve koşulsuz kararla eyleme geçerek gerçekleştirilir. İnsan, kendi varoluşunu aydınlığa çıkarabildiği gibi, burada oluşunun karanlığı içinde de bırakabilir. Martin Heidegger'e göre ise varoluş, insanı bütün öteki şeylerden ayırandır. Dünyanın içinde olmak insanın varoluşunun belirlenimidir. İnsanın burada olması bilinmeyen bir güç tarafındandır. İnsan buraya bırakılmış, burada oluşa zorlanmıştır. Dolayısıyla insan, varlığının kendi olanaklarını tasarlayabilmeli, yaratabilmeli ve gerçekleştirebilmelidir. İnsan özgür bir biçimde, kendi seçimleriyle oluşturduğu ve gerçekleştirdiği yaşamının kurucusudur. Bu geleceğe yönelen amaç, insanın var oluşunu anlamlı kılar ${ }^{20}$. Varoluşçu psikoloji, temellerini felsefenin bu üç önemli varoluşçu filozofunun düşüncelerinden alır ve tekniğini bu kökler üzerine inşa eder. 
Psikoterapi, insanı izah eden, insanın gelişimini açıklayan, felsefi ve bilimsel bir arka plana, bir insan modeline dayalı bir sistemi kabul ettikten sonra bu sistemden belirli nedenlerle sapma gösteren yapıların, belirli stratejilerle düzeltilmesini amaçlayan bilimsel bir disiplindir. Psikoterapötik ekoller; davranışçı, bilişsel, dinamik ve varoluşçu psikoterapiler olmak üzere dört temel başlık altında toplanmıştır. Varoluşçu psikoterapi; insanın en temel varlık nedenlerini irdeleyen ve cevap bulunamayan sorularla ilintili olarak insanın kriz yaşadığını iddia eden psikoterapi ekolüdür. Varoluşçu psikoloji ise, insanın kendisindeki ögelerin fonksiyonu aracılı̆̆ıla incelenemeyeceğini, insanı anlamada davranışçılık ya da psikanaliz türünden yaklaşımların yetersiz kaldığını savunan ve insanın "dünya içindeki varlık” olarak bireysel insan üzerinde yoğunlaştıran psikoloji anlayışıdır. Her insanın kendi içsel yaşamı, algıları, dünyayla ilgili değerlendirmeleri ve tepkileri açısından biricik olduğunu öne sürer ve insanı bütün bir varoluşsal gerçekliği içinde anlamaya çalışır. İnsanı özgürlük ve sorumluluk, yaşamın anlamı ve değerler, ölüm ve yalnızlık konuları açısından ele alır²1. Varoluşçuluk, psikiyatrideki konumu açısından değerlendirildiğinde bağımsız bir tedavi ekolü değil; insanı anlama çabasında, geleneksel psikolojik tedavilerin geleneksel yöntemlerinden farklı bir "tutum"dur. Bağımsız bir psikolojik tedavi ekolü olarak nitelendirilmemesinin nedeni sistematik bir kişilik kuramını içermemesidir. Bu nedenle varoluşçu tutumu benimseyen psikiyatristlerin çoğu psikanalitik kökenli kuramlardan yararlanırlar.

Psikiyatride varoluşçuluğun ilk uygulamaları 1950’lerde başlamıştır. Varoluşçu Psikiyatri, Medard Boss ve Ludwig Binswanger adlı iki İsviçreli psikanalistin psikanaliz ve filozof Heidegger'in ontolojisinin sentezini yaptıkları çalışmaları sonucu ortaya çıkmıştır. Varoluşçu yaklaşım, insanı birimler ve mekanizmalar topluluğu olarak açıklamak yerine “olmakta olan” bir varlık olarak anlamaya çalışır. Gerçek, yaşanan anda insanın kendi dünyasında yaşananlardır²2. Varoluşçu psikoterapi, belli davranış kalıplarının ve bunların arka planında yatan etmenlerin neler olduğunun bilinmesinin gerekliliğine vurgu yapar. Bu bilgilere ancak çalışma yapılan bireyle bir aradayken ve onun varoluş sürecinin içindeyken ulaşılabilir. "Ben”in algılanabilmesi ve yaşanabilmesine öncelik tanır. Beni yaşamak; bilinci, bilinçdışını ve insanın bütününü içerir. Anksiyete, düşmanlık ve saldırganlık yoğun biçimde yaşandığında insanın kendisiyle ve çevresiyle ilişkilerinde egemen olduğunda beni yok edebilir. Varoluşçu psikoterapi, bireyin var olmanın getirileriyle yüzleşmesinden kaynaklanan çatışmalar 
üzerinde durur. Bu getiriler yaratılıştan getirilen belirli niteliklerdir ve çatışma da ölüm, özgürlük, yalıtım ve anlamsızlıktan doğan dört nihai kaygıyı ifade etmektedir.

Ölüm: "Şu anda varız ama bir gün olmayacağız. Ölüm gelecek ve ondan kaçışın bir yolu yok.” İnsan bu gerçeğe derin bir korkuyla tepki verir. İnsanın ölümüyle yüzleşmesi ‘sınır durum'dur ve insanın hayatını nasıl yönlendirdiğini belirleyen bir güce sahiptir. Ölümün gelecek olmasının farkında olma, kişinin hayatı ve gündelik yaşam pratiklerini anlamlandırması açısında derinliği olan farklı bir bakış açısı kazandırır. Bu durumda ölüm kişiyi koruyan bir katalizör görevi görür.

Özgürlük: Özgürlük, insanın seçimleriyle kendini ve hayatını belirlemesidir. Dolayısıyla özgürlük kaygısı "sorumluluk” ile birliktedir. Kişi, sahip olduğu hayatı yaratmasındaki sorumluluğun kendisine ait olduğunun farkında olmalıdır. Kontrolü dışında meydana gelen olaylara verdiği tepkilerin ve bu tepkilerin hayatını nasıl yönlendirdiğine ilişkin farkındalık ve bu farkındalıkla seçim yapma bireyin sorumluluk alanına girer. Bu sorumluluğu üstlenmeyen kişi için hiçbir terapi çözüm vermez. İnsanın kendini ve dünyasını oluşturması ve sorumluluğunun farkında olması ürkütücüdür. $\mathrm{Bu}$ durumda insan sorumluluktan kaçınma davranışı gösterebilir ya da sorumluluğu inkâr edip masum kurban olduğunu düşünebilir. Ayrıca kişi, özgür olmadığını kendi dışında gözle görülmeyen güçlerin etkisi altında var olduğu bir dünya da yaratabilir. Böylece kişi özerk davranışlardan kaçınır ve karar verme süreçlerinde bozukluklar olur. Sorumluluğunun farkına varan hasta değişim kanalına girmiştir.

Yalıtım: İnsanlar var oluşa tek başına başlar ve varoluştan tek başına ayrılır. Buradan doğan varoluş çatışması ise, mutlak yalıtımın farkında olma ve bütünün bir parçası olma arzusu arasındaki gerilimdir. Yalom'a göre kişiler arası yalıtım, kişinin kendi içindeki yalıtımı ve varoluşsal yalıtım olmak üzere üç tip yalıtım vardır. Kişilerarası yalıtım yalnızlıktır ve diğer insanlardan ayrı ya da uzak olmaktır. Kişinin kendi içindeki yalıtım, insanın bazı içsel süreçlerini birbirinden ayırdığı yalıtımdır. Birey, hoş olmayan bir yaşantısını duygudan arındırır ve çağrışım bağlantıları bozulur, böylece sıradan düşünce sürecinden soyutlanır. Varoluşsal yalıtım ise kişi ile dünya arasındaki uçurumu ifade eder. Hiçbir ilişki bireyin yalıtımını yok edemez. Varoluşta her birey yalnızdır; ancak, yalnızlık paylaşılabilir ve sevgi yalıtım acısını telafi eder. Kişi yalıtılmışlığından kurtulmak için çeşitli bağlanma yolları geliştirir, kendi gereksinimini bastırabilir ve diğerlerinin isteklerini kendi istekleri haline getirebilirler. Yalıtım için “çözüm” yoktur. 
$\mathrm{Bu}$ var oluşun bir parçasıdır ve onunla yüzleşmek ve anlamak gerekmektedir. Grup çalışmasında, grup üyeleriyle etkileşimde bulunmak yalıtım korkusunu hafifletmede etkilidir. Ancak, bireylerin fark etmesi gereken en temel gerçeklerden biri, etkileşimin varoluşsal yalıtımı tamamen yok etmeyeceğidir. Grup lideri kişinin, varoluşsal yalıtımına doğrudan dikkatini vermesine, kaybolmuşluk ve yalnızlık duygularına dalmasına yardımcı olmalıdır. Böylece kişi yalıtımla yüzleşmeli ve onu kabullenmelidir.

Anlamsızlık: "Eğer ölmek zorundaysak, eğer kendi dünyamızı oluşturuyorsak, eğer her birimiz kayıtsız bir evrende tek başınaysak, o halde hayatın anlamı nedir? Neden yaşıyoruz? Nasıl yaşayacağız?” anlamsızlık duygusunun temelindeki sorulardır. Anlamsızlık duygusu varoluşsal krizin nedenidir. Varoluşsal kriz, hayattaki anlam arayışındaki başarısızlıktan kaynaklanır. Başarısızlık insanın yaşamaya, mücadeleye, umut etmeye değecek bir şey olmadığı duygusuna kapılması, hayatta bir amaç ya da bir yön bulamama olarak kendini gösterir. İnsanın yaşam için bir anlam bulma çabası onun için yaşamını sürdürmede motivasyonel bir güçtür. Hayatın anlamıyla ilgili soruların yapısının iyi analiz edilmesiyle soruya neden olan ve aslında başka konuları ifade eden sorunun çözümlenmesi anlam krizini hafifletir. Grup lideri ayrıca, anlama karşı bir bakış açısı sunarak kişiye anlamın göreceli olduğunu kabul etmesini sağlayarak yardımcı olabilir ${ }^{23}$.

\section{Çocukluk Çağı Cinsel İstismarına Maruz Kalan Bireylerle Varoluşçu Sosyal Grup Çalışması}

Sosyal Grup Çalışması, sosyal hizmetin mezzo müdahale düzeyinde uyguladığı bir çalışma yöntemidir. Bireylerin sosyal fonksiyonlarında içsel ya da dışsal herhangi bir etkiyle ortaya çıkan sorunlarıyla baş edebilmeleri amacıyla onlara yardım eden, kendine özgü kuralları ve teknikleri olan bir süreçtir. Aynı sorunu yaşayan bireylerin grup çalışması kural ve tekniklerine uygun olarak bir araya getirilmesi, sorunla ilgili yaşam deneyimlerinin paylaşılması, etkileşim kurulması, grup liderinin yönlendirmesiyle bu etkileşim sürecinin bireylerde iyileşmeyi, değişimi ve güçlenmeyi sağlaması amaçlanır. Grup deneyimi, bireylerin uyum sağlayıcı beceriler geliştirebilmelerinde, uyum bozucu olan davranışlarının giderilmesinde çok hızlı yardım sağlayan bir yöntemdir²4.

Cinsel istismar travmasının etkileri çok derin ve köklüdür. Etkileri bu kadar güçlü olan travmatik bir olayın tedavi süreci de zorludur. Küçük yaşlarda fiziksel acı ile birlikte 
yıkılan duygusal ve ruhsal dünyanın yeniden inşası, kişinin bu acı olay sonucu edindiği bakış açısının ve zihinsel yaklaşımının dönüştürülmesi ve olayın etkilerinin en aza indirilerek, olumlu kazanımlarla hayata devam etmesinin sağlanması zahmetli bir süreçtir. Bu süreçte yaşananların tekrar hatırlanması, geri dönüşlerle gelen duygusal çöküntüler de süreci iyice zorlaştırmaktadır. Cinsel istismara maruz kalanlarla yapılan çalışmaların öncelikle bireysel terapiyle başladığı ve sonra grup terapisine alındıkları görülmektedir. Sürecin bu şekilde işlemesi olayın üzerindeki etkileri azaltılmış bireyi grup sürecine ve diğer insanlarla paylaşmaya hazırlamak açısından önemlidir. Olayın ve bireyin mahremiyeti açısından bireysel terapi güven ve gizliliğin sağlandığı korunaklı alan açısından önemli olsa da, damgalanma, utanç gibi duyguların üstesinden gelmek için grup terapisine de katılım oldukça önemlidir. Ayrıca travmayı atlatmak ile ilgili çalışmalarda akran arkadaşlığının ve desteğinin yoksunluk duygusunun iyileşmesinde en önemli faktör olduğu kanıtlanmıştır ${ }^{17}$. Grup üyelerinden alınan destek bu acılı ve korkulu sürecin daha rahat atlatılmasında etkilidir. Sosyal grup çalışmasının etkililiğini anlamak için sosyal grup çalışmasının bireylerin psikolojik gereksinimlerine etkisini belirlemek amacıyla yapılan bir çalışmada duyguları anlama gereksinimi en öncelikli gereksinim olarak ortaya çıkmıştır. Ek olarak grup sürecinde üyelerin kendini tanıma olanağı bulduğu ve bunun sonucunda oldukları gibi görünme, yakınlık gereksiniminin ön plana çıktığı ve kendini suçlama gereksinimin azaldığı tespit edilmiştir²5.

2003 yılında “Travma Yaşantısı Olan Kadınlarda Grup Psikoterapisinin Etkinliği” adlı bir çalışmada ise yaşları 18-43 arası değişen, yaş ortalaması 31 olan, 15 ve 18 kişilik iki grup olmak üzere 33 kadınla çalışılmıştır. Grup üyeleri arasında, eşin cinsel ve fiziksel şiddeti \%33, baba ve abi tarafından cinsel taciz ise \%15 oranında tespit edilmiştir. Grup çalışmaları beş ay süre ile ayda bir, hafta sonları iki gün olmak üzere toplam 10 gün ve 60 saatte tamamlanmıştır. Grup sonlandığında önemli aktivitelere katılmama, duygusal donukluk, geleceğe yönelik planların olmaması, umutsuzluk, aşırı gerginlik, öfke, dikkat toplama güçlüğü, uyku bozukluğu gibi depresif semptomlarda iyileşme görülmüştür ${ }^{14}$.

Uluslararası örnekler incelendiğinde ise ensest ve cinsel istismara maruz kalanlar için Amerika'da Dr. Judith Herman tarafından geliştirilen üç aşamalı bir tedavi modeli ön plana çıkmaktadır. Bu model hem bireysel terapilerde hem de grup çalışmalarında kullanılmaktadır. Herman’ın modeline göre iyileşmenin üç aşaması kişinin somut öz bakımı, travmanın yeniden yapılandırılması ve yeniden bağlanma aşamalarından 
oluşmaktadır. Buna göre kişinin somut öz bakımı aşamasında bedenin bakımı ve kontrolü; uyku düzeni, yemek, bağımlılıklar, tıbbi geçmiş, eş zamanlı hastalık, güvenli çevre oluşturma; ev, iş, okul, finans, kendine zarar vermenin kendini rahatlatma ile yer değiştirmesi; müzik dinleme, okuma, güvenilir bağlılıklar, sosyal destek sistemleri; kendine yardım, din, sosyal destek gruplarına katılıma odaklanılır. Travmanın yeniden yapılandırılması aşamasında ise çözülme küçük adımlarla gerçekleşir. Bireyler bir an önce bu durumu aşmak ister; ancak yavaş gitmek hastayı zorlu duygu ve düşüncelerden koruyacaktır. Hafıza, biliş ve duyguların bütünleşmesi önemlidir. Varoluşsal bir sorun olan “Neden ben?” sorusuna ve varoluşun acısına yeni bir anlam vermek gerekir. Travma sonrası mevcut deneyimler ile travma geçmişinde yaşananların bağlantısını keşfetmek önemlidir. Üçüncü aşama olan yeniden bağlanma aşamasında, soyutlanma, utanç, damgalanma duygularını azaltma, aileyle ilişkilerin yeniden görüşülmesi ve yapılandırılması, akranlarla yeni arkadaşlıklar kurulması, yakın ve cinsel bir ilişki geliştirilmesi, sosyal hareketlilik, başarılı bir yaşam döngüsü geliştirme amaçlarını gerçekleştirmeye odaklanılır'15. Cinsel istismar mağdurlarının varoluşsal bir sorgulamaya girmesi kendilerini ve istismar deneyimlerini hayatlarının konumlandırmaya çalışması ve bunu yaparken cinsel istismar deneyiminden doğru bir konumlandırmaya girişmesi baş etme mekanizmalarının bir sonucudur ve sıklıkla ortaya çıkar. Görüldüğü gibi iyileşmenin üç aşamasında bireylerin kendilerini varoluşsal açıdan sağlıklı ve doğru yönlendirilmiş bir bağlam içinde yeniden inşa etmeleri bu çalışmanın en önemli ve terapötik etkisi en yüksek bölümüdür. Dolayısıyla varoluşçu yaklaşımın cinsel istismar mağdurları için grup çalışmasında kullanılması faydalıdır.

Varoluşçu grup çalışmasında odak, grup üyelerinin grup çalışması esnasındaki varoluşlarını algılayabilmeleri ve diğer grup üyelerine bunu kendileri açısından yaşatabilmeleridir. Varoluşçu grup çalışması sürecinde, grubun başlangıcında önceden bir yapı sunulmamış olduğu için bir sessizlik yaşanır ve bu durum üyelerin çoğunun çeşitli biçimlerde anksiyete yaşamasına neden olur. Üyelerin varoluş sorumlulukları kendilerine bırakıldığı için grup liderinin üyelerin kendilerini nasıl yaşayacaklarına ilişkin bir beklentisi de yoktur. Gerçek dünyada olduğu gibi kişiye kendisinden başka yol gösterecek de yoktur ${ }^{22}$. Ancak, başlangıçta üyelerin grup liderine tutunmaya çalışmalarına izin verilebilir. Grupta yol alındıkça sessizlik süreleri ürkütücü gelmemeye başlar. 
Varoluşçu grup deneyimi hayat deneyiminin mikro kozmosudur. Sosyal grup çalışması da dış dünyanın bir temsilidir ve bu açıdan varoluşçu grup terapisiyle ortak bir payda da buluşmaktadırlar. Varoluşçu grup çalışmasında, grup lideri, grup üyelerinin kendi sorunlarında oynadıkları rolü belirlemeli ve bu iç görüyü üyelere fark ettirmelidir. Varoluşçu grup çalışmasının en etkileyici yönlerinden biri bütün üyelerin aynı anda doğuşudur. Her biri gruba eşit durumda başlar. Her biri diğer üyeler tarafından görülen ve kendisinin de gördüğü bir şekilde grupta aşama aşama belirli bir hayat alanı şekillendirir. Böylelikle kişi kendisi için grupta (ve benzer şekilde hayatta) aldığı kişilerarası mevkiden ve başına gelen olaylardan sorumlu olur ${ }^{23}$. Varoluşçu sosyal grup çalışmasının grup üyelerinin kendileri hakkında dürüst olmaları için kolaylaştırıcı olmak, üyelerin kendileri ve çevrelerindeki dünya ile ilgili bakış açılarını genişletmek, yaşamlarına ve geleceklerine anlam veren şeyleri fark ettirmek, yelerin yaşam görevlerinin tam olarak farkında olmalarını sağlamak, amaçlarını belirleyip sorumluluklarının farkına varmalarına yardım etmek ve tüm bunları sağlayarak yaşadıkları travmanın etkilerinin yaşamlarına egemen olmasına izin vermeden bireylerin güçlendirilmesine katkıda bulunmak şeklinde amaçları vardır. Grup çalışması ile soyutlanma ve yabancılaşma duygularında azalma, güven duygusunun beslenmesi, benzer deneyimi yaşayanlar tarafindan anlaşılma duygusudur. Grup çalışması, üyelere sessizliklerini bozma ve kendilerine olanlar hakkında konuşma cesareti verir. Ayrıca, suçluluk ve utanç duygularının keşfedilip çözümlenmesi için güvenli bir alan oluşturur ${ }^{20}$. Cinsel istismarın negatif ve travmatik sonuçlarını azaltmak (anksiyete, depresyon, davranış problemleri), sosyal izolasyonu azaltmak, utanç ve suçluluk duygularını azaltmak, ensestin etkileriyle başa çıkabilmeleri için kişisel kaynaklarına güvenmek ve kullanmak konusunda yardımcı olmak cinsel istismara maruz kalan bireyler için varoluşçu grup terapisinin amaçlarıdır²6. Bu amaçlar sosyal hizmet uygulama yöntemlerinden olan sosyal grup çalışmasının amaçlarıyla da doğrudan örtüşmektedir.

Varoluşçu yaklaşımı kullanan bir grup liderinin, grup üyesi ile birlikte grup sürecinde yaşananlara odaklanması, empati kurması ve doğrultuda bir dinleme yeteneğinin olması gerekir. Bireyi "onun kendi dünyası” içinde anlamaya çalışmalı, yargılamaktan kaçınmalıdır. İyileştirme sürecinin içeriğine odaklanmalı ve grup üyelerini yönlendirmeden teşvik etmelidir. Empati kurma, bireyin olduğu yerden başlama, 
önyargısız olma sosyal çalışmacının da hem görevleri hem de mesleki etik standartlar içinde yer alan ilkelerdir ve grup lideri olarak bu ilkelere uymakla yükümlüdür.

Çocukluk çağı cinsel istismarına yönelik iyileştirmede, travmatik anılarla ilişkili duygusal süreçlerin çalışılması tedavinin temel noktasını oluşturur. Üst düzey savunma düzeneklerinin geliştirilmesi, ego kapasitesinin arttırılması, sosyal aktivitelere, becerilerine uygun bireysel etkinliklere yönlendirilmesi amaçlanır. Damgalanma ile ilgili suçluluk duygusu ve benlik saygısındaki azalmanın giderilmesi için bireyin bir cinsel aktiviteye dâhil edilmesinin herhangi bir şekilde kendi suçu olmadığı ve suçlunun davranışının bozuk ve hastalıklı bir davranış olduğu anlatılmalıdır. Tüm bu etkilerin şimdiki zamandaki etkilerinin ve gelecekteki potansiyel etkilerinin azaltılması ve sağaltılmasında varoluşçu yaklaşım kullanılabilir. Cinsel istismar hassas, mahremiyeti ve gizliliği olan bir konu olduğu için grup çalışmasının ideal olarak 7-8 kişilik kapalı grup şeklinde dizayn edilmesi, ortalama seans sayısının on iki - on dört olması ve bir seansın süresinin ortalama doksan dakika olması ideal görülmektedir.

Varoluşçu psikoterapinin bireyin, var oluş çabasından kaynaklanan çatışmalar üzerinde durmaktadır. Çocukluk çă̆ı cinsel istismarına maruz kalanların yaşadıkları olayın etkisiyle edindikleri kendi hayatlarına dair çatışma durumları ve bunlara eşlik eden düşünceler ve duygular çocuk yaşlarından itibaren süre geldiği için varoluşlarının bir parçası durumuna gelmiştir. Dolayısıyla varoluşçu yaklaşımın ölüm, sorumluluk, yalnızlık ve anlamsızlık odağında çözmeye çalıştığı çatışmalar, cinsel istismara maruz kalanların varoluş krizleri ya da çatışmalarını çözmek için de kullanışlı ve etkilidir. $\mathrm{Bu}$ noktada varoluşçu teorinin bu dört çatışma odağından hareketle, çocukluk çağı cinsel istismarına maruz kalanların yaşadığı dört temel çatışma durumunu incelemek ve hangi çatışmaya hangi varoluş odağının çözüm getirebileceğini analiz etmek önemlidir.

\section{Sonuç}

Bireyin yaşadığı travmatik cinsellik sonucu gelişen cinsel kimlik karmaşası ve cinsellik ve sevginin karıştırılması çatışmasının giderilmesi için bireyin bütüncül varoluşçu terapi yoluyla cinsel kimliğinin farkına varması ve kendi cinselliğinin kapsamını keşfetmesi sağlanır. Cinsellik ve sevginin karıştırılmaması, oluşturulan bu farkındalık üzerinden varoluşçu çalışmanın odaklarından biri olan anlamsızlık çatışmasında sevginin işlevi üzerinden terapiye devam edilmesiyle mümkün olur ${ }^{27}$. 
Çocukluk döneminde cinsel istismara maruz kalan bireyin yaşadığı ikinci çatışma durumu olan ihanet duygusu ise onu sevmesi ve koruması gereken birinin ona zarar verdiğini fark etmesiyle gelişir. Depresyon, bağımlılık, güvensizlik, öfke ve düşmanlık duyguları ile sonuçlanır. Üçüncü çatışma durumu olan damgalanma ise çocuğun suçlanması ve çocuğa "kirli ve bozulmuş” olduğu mesajının verilmesidir. Suçluluk, utanç, düşük benlik saygısı ve soyutlanma ile sonuçlanır. Bu çatışmalar ve etkileri varoluşçu teorinin özgürlük ve yalıtılmışlık odağı ile ele alınır. Buna göre, bireye özgür olduğu ve hayatına kendi seçimleriyle yön verdiği, geçmişte yaşadığı olayın şimdiki zamanını ve geleceğini çalmasına izin verip vermemesinin sorumluluğunun ve bununla baş etme gücünün yine kendisinde olduğu fark ettirilmelidir. Birey, kendi iradesi dışında ve başka bir güç tarafından zorla yapılan bu eyleme engel olamadığı için yaşadığı suçluluk duygusu yaşar ve bu duygudan kurtulamaz. Bu durumda bireye kendi dışında gelişen bu olaydan sorumlu olmadığı ve kişinin kendisini şu an ve gelecek için bağışlamayı öğrenmesi gerektiği hatırlatılır.

Varoluşun acılarından biri olan yalıtım ve yalnızlık, çocukluk çağında cinsel istismara maruz kalan bireyin yaşadığı soyutlanmışlık duygusuyla benzerdir. Bireye yaşanılan olumsuz deneyim açısından yalnız olmadığının grup ortamında deneyimletilmesi, grup üyeleriyle alışverişte bulunma ve paylaşım yalıtım korkusunu hafifletmede etkili olacaktır. Çocukluk döneminde cinsel istismara maruz kalan bireyin yaşadığı soyutlanma duygusu, grup sürecinde grup liderinin yönlendiriciliği ile aslında herkesin bir şekilde kendini hem kişilerarası ilişkilerde hem de kendi benliği içinde soyutlanmış ve yalnız hissettiği odağı üzerine çevrilir. Böylece yalıtılmışlık duygusunun, kaynağı bireysel düzlemde hangi nedenden kaynaklanırsa kaynaklasın, herkesin ortak olarak deneyimlediği bir fenomen olduğu, bunun varoluşun bir parçası olduğu ve asıl olanın bu duyguyla baş etmede bireyin, “çevresi içinde birey” yaklaşımı uyarınca yakın çevresi başta olmak üzere sosyal destek sistemlerinden yararlanmasının öneminin vurgulanmasıdır. Bunun için uygun ortamın oluşturulması gerekmektedir. Kullanım hem bireyin çabasına bağlıdır ki bu, grup liderinin verdiği grup çalışması ve ödevlerle pekiştirilir hem de sosyal hizmetin konu özelindeki uygulamalarının işlevsel olmasına bağlıdır. Örneğin; konu odağında sosyal destek sisteminden yoksun olan bireylerin cinsel istismar konusunda faaliyet gösteren sivil toplum örgütlerinden veya ilgili kamu kurumlarından ihtiyaç duyduklarında sosyal destek almalarının sağlanması gerekir. 
Çocukluk döneminde cinsel istismara maruz kalan bireyin yaşadığı dördüncü çatışma, güçsüzlüktür. Çocuğun bedeninin şiddete uğraması ve çocuğun şiddeti ve istismarı durdurmakta yetersiz hissetmesiyle gelişir ve sonuçta anksiyete, korku ve öz yeterliliğin zayıflaması duyguları olarak açığa çıkar. Varoluşçu teorinin sınır durum olarak betimlediği ölüm korkusu ile çocukluk döneminde cinsel istismara maruz kalan bireyin yaşadığı ve artık varoluşunun bir parçası haline gelen korku eş değer sayılabilir. Ölümün farkında oluş ve cinsel istismar mağdurlarının yaşadıkları travmanın onlar için yarattığı sınır durum bu noktada kişilerin bakış açısını değiştirmek için kullanılabilir. Grup çalışmasıyla grup üyelerine sınır durumu ve bu durumdan hareketle yaşama şeklinde değişim yapma gücünün elinde olduğu fark ettirilir. Ayrıca varoluşsal krizin en önemli çözüm yollarından olan amaç belirlemeyle çözümlenen anlam bulma durumu ve kendi hayatı için sorumluluk alma bireyin özyeterliliğin gelişmesine yardımcı olacaktır.

Varoluşçu sosyal grup çalışması, tüm bu çalışmaların grup lideri ve grup üyeleriyle bir arada çözümlenmesi sürecidir. Varoluşçu sosyal grup çalışması farkındalık, bilinç ve bireyin düşünme sisteminde dönüşümü sağlayarak çocukluk döneminde cinsel istismara maruz kalan bireylerin yaşadıkları olayın etkilerini sağlanabilecek en az seviyede hissetmeleri, yaşamlarını sürdürme ve baş etme becerileri açısından daha güçlü ve daha donanımlı olmalarını sağlayacak bir yöntem olarak kullanılabilir. Bunun yanı sıra cinsel istismarın birey üzerindeki etkilerinin hafifletilmesi ve bireyin biyopsikososyal açıdan sağlıklı bir yaşam sürdürmesi için konuyla ilgili sosyal hizmet kaynaklarının ve uygulamalarının sürecin bir parçası olduğu unutulmamalı ve bireyin ihtiyaç duyması halinde erişilebilir olmaları ve destek hizmetleri olarak sunulması gerekmektedir.

\section{KAYNAKÇA}

1. Modelli MES, Galvao MF, Pratesi R. Child sexual abuse. Forensic Science International. 2012;(217):1-4.

2. Uluslararası Sosyal Hizmet Çalışanları Federasyonu. Sosyal hïzmetïn küresel tanımı. Uluslararası Sosyal Hizmet Çalışanları Federasyonu. https://www.ifsw.org/what-is-social-work/global-definition-of-social-work/ . Erişim Tarihi 20 Kasım 2020. 
3. UNICEF. Çocuklara Kötü Muamelenin Önlenmesi: Bu Konuda Harekete Geçilmesine ve Kanıt Toplanmasına Yönelik bir Kılavuz. https://apps.who.int/iris/bitstream/handle/10665/43499/9241594365 tur.pdf ?sequence $=21 \&$ isAllowed $=y$ Erişim Tarihi 20 Kasım 2020.

4. Page AZ. Çocuk cinsel istismarı: cinsel istismara neden olan etkenler ve cinsel istismarın çocuklar üzerindeki etkileri. Türk Psikoloji Yazıları. 2004;7(13):103 113 .

5. Topçu, S. Cinsel İstismar. Ankara: Phoenix; 2009.

6. Dağll, T, ed. Çocuğun Cinsel İstismarı, Çocuğa Yönelik Şiddet ve Çocuğun Korunması. Çocuk Koruma Merkezlerini Destekleme Derneği. 41-51.

7. World Health Organisation. Geneva: Preventing Child Maltreatment: A Guide To Taking Action and Generating Evidence. World Health Organisation. https://apps.who.int/iris/bitstream/handle/10665/43499/9241594365 eng.pd f?sequence=1\&isAllowed=y Erişim Tarihi 20 Kasım 2020.

8. Şahin F, Taşar MA. Cinsel istismar ve ensest. Türk Peidatri Arşivi. 2012;47(3):159-164.

9. World Health Organisation, Guidelines for Medico-legal Care for Victims of Sexual Violence. Geneva, 2003.

10. Nüfusbilim Derneği ve Birleşmiş Milletler Nüfus Fonu, Ankara: Türkiye'de Ensest Sorununu Anlamak https://turkey.unfpa.org/sites/default/files/pubpdf/ensesrapor.pdf Yayınlanma Tarihi 2009. Erişim Tarihi 30 Eylül 2018.

11. ECPAT Bilgilendirme Raporu 2020. https://www.ecpat.org/wpcontent/uploads/2020/07/ECPAT-Country-Overview-Report-SexualExploitation-of-Children-inTurkey-TURKISH.pdf Erişim Tarihi 30 Eylül 2020.

12. TÜİK. https://biruni.tuik.gov.tr/medas?kn=98\&locale=tr. Erişim tarihi 10 Temmuz 2020.

13. Çavlin-Bozbeyoğlu A. Türkiye'de ensest sorununu anlamak. https://turkey.unfpa.org/sites/default/files/pub-pdf/ensesrapor.pdf Yayınlanma Tarihi 2009. Erişim Tarihi 10 Temmuz 2020.

14. Sezgin U. Travma yaşantısı olan kadınlarda grup psikoterapisinin etkinliği. Nöropsikiyatri Arşivi. 2003;40(3-4):53-63.

15. Stice P. Group therapy for survivors of childhood abuse professional training. USA: the clearing house for structured/thematic groups \& innovative programs, 
2007. http://www.complextrauma.uk/uploads/2/3/9/4/23949705/pto07.pdf. Yayınlanma Tarihi 2007. Erişim Tarihi 10 Ekim 2018.

16. Thun D, Sims P, Adams M. Effects of group therapy on female adolescent survivors of sexual abuse: a pilot study. Journal of Child Sexual Abuse. 2003;11(4):1-16.

17. Aktepe E. Çocukluk çağı cinsel istismarı. Psikiyatride Güncel Yaklaşımlar. 2009;1:95-119.

18. Johnson CF. Child sexual abuse. Lancet. 2004;364:462-470.

19. Cevizci A. Paradigma Felsefe Sözlüğü. İstanbul: Paradigma; 1999.

20. Akarsu B. Çağdaş Felsefe. İstanbul: İnkılap; 1994.

21. Özakkaş T. Bütüncül Psikoterapi. İstanbul: Litera Yayıncılık; 2013.

22. Geçtan E. Varoluş ve Psikiyatri. İstanbul: Metis; 2002.

23. Yalom I. Varoluşçu Psikoterapi. İstanbul: Kabalc1; 2013.

24. Duyan V. Sosyal Hizmet Temelleri, Yaklaşımları, Müdahale Yöntemleri, Sosyal Hizmet Uzmanları Derneği; 2012.

25. Duyan V, Gökçearslan E. Sosyal Grup Çalışmasının Psikolojik Gereksinimlere Etkisi Toplum ve Sosyal Hizmet. 2004;15(1):61-73.

26. Tourigny M, Hébert M, Daigneault I, Simoneau C. Efficacy of a group therapy for sexually abused adolescent girls. Journal of Child Sexual Abuse. 2005; 14(4):71-93.

27. Finkelhor D, Browne A. The traumatic impact of child sexual abuse: a conceptualization. American Journal of Orthopsychiatry. 1985;55(4):530-541. 